\title{
EFEK EKSTRAK ETANOL GANGGANG HIJAU (Ulva lactuca, L) TERHADAP EKSPRESI COX-2 MIOKARDIUM TIKUS YANG DIINDUKSI ISOPROTERENOL
}

\section{THE EFFECT OF GREEN ALGAE ETHANOL EXTRACT IN REDUCING EXPRESSION OF COX-2 IN ISOPROTERENOL-INDUCED IMA RATS}

\author{
Wahyu Widyaningsih ${ }^{1 *}$, Nina Salamah ${ }^{1}$, Suwidjiyo Pramono ${ }^{3}$, \\ Sitarina Widyarini ${ }^{2}$, Sugiyanto ${ }^{3}$ \\ ${ }^{1}$ Fakultas Farmasi Universitas Ahmad Dahlan, Jl. Prof. Dr. Soepomo, Yogyakarta \\ ${ }^{2}$ Fakultas Kedokteran Hewan Universitas Gadjah Mada, Jl. Fauna No. 2, Yogyakarta \\ ${ }^{3}$ Fakultas Farmasi Universitas Gadjah Mada, Jl. Sekip Utara, Yogyakarta, \\ *Penulis Korespondensi, e-mail : widyaningsihwahyu@yahoo.com
}

\begin{abstract}
ABSTRAK
Penyakit kardiovaskuler masih merupakan masalah di Indonesia salah satunya adalah Infark Miokardial Akut (IMA). Patofisiologis AMI karena rective oxigen spesies (ROS) melibatkan stimulasi sitokin pro inflamasi salah satunya adalah interleukin-1 yang berakibat peningkatan ekspresi COX-2. Penelitian ini bertujuan mengetahui efek ekstrak etanol ganggang hijau dalam menurunkan ekspresi COX-2 pada tikus IMA yang diinduksi isoproterenol (ISO). Ekstraksi ganggang hijau dengan maserasi menggunakan etanol 96\%. Tikus berat 200-250 g dibagi menjadi 6 kelompok masing-masing 6 ekor. Kelompok I kontrol, tikus tidak diberi ISO hanya diberi CMC Na, kelompok II kelompok ISO, tikus diberi CMC Na dan ISO, kelompok III, IV dan V tikus diberi ekstrak etanol ganggang hijau dosis 250, 500 dan $750 \mathrm{mg} / \mathrm{KgBB}$ peroral dan kelompok VI diberi melatonin $10 \mathrm{mg} / \mathrm{KgBB}$. Perlakuan ekstrak selama 28 hari. Pada hari ke 29 dan 30 tikus diberi isoproterenol dosis $85 \mathrm{mg} / \mathrm{KgBB}$ selama 2 kali pemberian secara subkutan kecuali kelompok I. Pada hari ke 31 tikus diambil organ jantung kemudian dibuat preparat histologis dan dilakukan analisis ekspresi COX-2 dengan metode imunohistokimia dengan antibodi anti COX-2. Hasil penelitian menunjukkan bahwa pemberian ekstrak etanol ganggang hijau dosis 250,500 dan $750 \mathrm{mg} / \mathrm{KgBB}$ dapat menurunkan ekspresi COX-2 pada tikus yang diinduksi isoproterenol.
\end{abstract}

Kata kunci: COX-2, Ulva lactuca L, isoproterenol, melatonin

\section{ABSTRACT}

Cardiovascular disease is still a problem in Indonesia, one of the problem is acute myocardial infarction (IMA). The pathophysiology of AMI due to reactive oxygen species (ROS) involves stimulation of pro-inflammatory cytokines one of which is interleukin-1 which results in increased COX-2 expression. This study aims to determine the effect of green algae ethanol extract in reducing expression of COX-2 in isoproterenol-induced IMA rats (ISO). Green algae extraction by maceration using 96\% ethanol. Rats 200-250 gBW divided into 6 groups of 6 each. Group I control, mice not given (ISO) were given only CMC Na, group II group of ISO, mice were given CMC Na and ISO, group III was given melatonin $10 \mathrm{mg} / \mathrm{KgBW}$, group IV, V and VI mice were given ethanol extract of green algae dose 250, 500 and $750 \mathrm{mg} / \mathrm{Kg} \mathrm{BW}$. Treat the extract for 28 days. On day 29 and 30 mice were given Isoproterenol dose $85 \mathrm{mg} / \mathrm{KgBW}$ for 2 times subcutaneously except group I. On day 31 mouse was taken heart organ then made histological preparation and conducted analysis of expression of COX-2 with immunohystochemical method with anti-COX-2 antibody. The results 
showed that ethanol extract of green algae dose 250, 500 and $750 \mathrm{mg} / \mathrm{KgBW}$ can decrease expression of COX-2 in isoproterenol-induced rats.

Keywords: COX-2, Ulva lactuca L, isoproterenol, melatonin

\section{PENDAHULUAN}

Menurut WHO sampai tahun 2020 penyakit kardiovaskuler merupakan penyebab kematian terbesar di dunia. Diperkirakan penyakit jantung dan stroke akan meningkat mencapai 23,3 juta pada 2030 (WHO, 2016). Salah satu penyakit kardiovaskuler adalah infark miokard akut (IMA). Pada IMA, Reactive Oxigen species (ROS) menyebabkan secara langsung luka pada membran yang dihubungkan dengan sitokin pro inflamasi antara lain interleukin (IL)-1 dan IL-6 (Rodrigo et al., 2013). IMA dikaitkan dengan inflamasi pada jaringan. Ekspresi COX-2 yang berlebihan ditemukan berhubungan dengan peningkatan produksi PGE2 pada iskemia jantung. Ekspresi COX-2 memacu berbagai sel untuk meningkatan produksi prostaglandin (PG) (Carnieto et al., 2009). COX-2 memiliki sifat-sifat lainnya, termasuk penghambatan fibrosis, trombosis dan peradangan (Gimbrone et al., 2000). Hal tersebut berkaitan dengan peran kardioprotektif dari COX-2.

Salah satu metode standar untuk induksi infark miokard pada tikus adalah dengan pemberian isoproterenol (ISO) yang merupakan agonis $\beta$ adrenergik non-selektif (Grimm et al., 1998; Rathore et al., 1998). Stimulasi reseptor $\beta$-adrenergik menghasilkan spesies oksigen reaktif (ROS) (Zhang et al., 2005). Mekanisme infark miokard akibat pemberian ISO menyebabkan disfungsi jantung, peningkatan lipid peroksidasi, mempengaruhi aktivitas enzim dan antioksidan di otot jantung (Rathore et al., 1998).

Organisme laut merupakan sumber metabolit sekunder yang penting dalam pengembangan agen farmasetik (El Gamal, 2010). Spesies ganggang (Ulva Sp) banyak terdapat di habitat pantai di seluruh dunia (Einav dan Israel, 2007). Ulva sp (ganggang hijau) merupakan sumber alam yang berpotensi dalam bidang bidang kefarmasian (El Baky et al., 2009; Martinez et al., 2005; Robic et al., 2008). Ulva lactuca L merupakan salah satu spesies algae yang mempunyai komponen bioaktif seperti senyawa fenolik, polisakarida sulfat (Sathivel et al, 2008), klorofil (0,5608 mg/g), karotenoid $(0,785 \mathrm{mg} / \mathrm{g})$, vitamin C $(42,6 \mathrm{mg} / \mathrm{g})$ dan polifenol (5,45 mg) (Abirami dan Kowsalya, 2011) dan melatonin (Hardeland dan Poeggeler, 2003; Pape dan Lüning, 2006; Paredes et al., 2009). U. lactuca mengandung melatonin 12 pg/g berat basah (Pape and Lüning, 2006). Ekstrak etanol U. Lactuca 
mengandung melatonin sebesar $0,74 \mathrm{mg}$ melatonin dalam $100 \mathrm{mg}$ ekstrak (Widyaningsih et al., 2016). Hasil skrining fitokimia menunjukkan bahwa ektrak etanol U.lactuca dari pantai Drini mengandung flavonoid, alkaloid dan klorofil (Widyaningsih et al., 2016).

Tanaman ganggang cukup efektif sebagai obat pada penyakit kardiovaskuler (Paredes et al., 2009). Penelitian terdahulu menunjukkan bahwa pemberian ekstrak etanol terstandar melatonin dari $U$. lactuca mempunyai efek kardioprotektif dengan memperbaiki gambaran EKG, mengurangi luas area infark dan menurunkan enzim penanda kerusakan jantung seperti kreatinin kinase (CK) dan laktat dehidrogenase (LDH) (Widyaningsih et al., 2016), menghambat apoptosis dengan menurunkan ekspresi caspase-3 dan mempunyai aktivitas antioksidan endogen (Widyaningsih et al., 2017) pada tikus yang diinduksi ISO. Penelitian ini bertujuan untuk mempelajari efek ekstrak etanol ganggang hijau (EEGH) terhadap ekspresi COX-2 miokardium tikus yang diinduksi ISO yang digunakan sebagai dasar mekanisme kardioprotektif pada proses inflamasi dengan parameter penghambatan ekspresi COX-2.

\section{METODE PENELITIAN}

\section{Bahan dan Alat Penelitian}

Bahan utama yang digunakan dalam penelitian ini sama dengan penelitian sebelumnya (Widyaningsih et al., 2016; Widyaningsih et al., 2017) yaitu ganggang hijau (U. lactuca L) yang diperoleh dari pantai Drini Kabupaten Gunung Kidul pada bulan Januari 2015 saat air laut surut. Identifikasi tanaman ganggang hijau dilakukan di Laboratorium Taksonomi Tumbuhan Fakultas Biologi Universitas Gadjah Mada dengan nomer 0626/S.Tb/I/2015. Bahan kimia lainnya adalah etanol 96\% sebagai bahan pengekstraksi, reagen kit untuk IHC dan melatonin standar (Sigma). Hewan uji yang digunakan dalam penelitian adalah tikus jantan galur Wistar, umur 2-3 bulan berat 200-250 gram.

Jalannya Penelitian

Ekstraksi gangangg hijau. Ganggang hijau (U. lactuca $\mathrm{L}$ ) didiamkan dalam air laut selama 7 jam dalam wadah tertutup. Ganggang kering kemudian diserbuk menggunakan blender. Serbuk ganggang hijau kemudian diekstraksi dengan metode maserasi menggunakan 
etanol 96\% sebagai pelarutnya. Sari etanol ganggang hijau kemudian diuapkan pelarutnya dengan rotary evaporator pada suhu $40^{\circ} \mathrm{C}$ hingga diperoleh ekstrak kental.

Perlakuan Hewan Uji. Hewan uji berupa tikus Wistar, jantan, umur 2 bulan, berat 200$250 \mathrm{~g}$, dibagi menjadi 6 kelompok masing-masing 6 ekor. Semua perlakuan terhadap hewan uji sudah mendapat ethical clearance dari Laboratorium Penelitian dan Pengujian Terpadu (LPPT) Universitas Gadjah Mada dengan Nomor 205/KEC-LPPT/XII/2014. Sebelum mendapat perlakuan, tikus diadaptasikan selama 1 minggu dengan kondisi laboratorum pada suhu kamar. Hewan uji mendapatkan pakan dan minum ad libitum.

Pengelompokan hewan uji adalah sebagai berikut :

Kelompok I : Kelompok normal mendapatkan $\mathrm{NaCl}$ fisiologis tanpa induksi isoproterenol.

Kelompok II : Kelompok kontrol negatif mendapatkan $\mathrm{CMC} \mathrm{Na}$ dan diinduksi isoproterenol dosis $85 \mathrm{mg} / \mathrm{KgBB}$.

Kelompok III: Kelompok EEGH 250 mendapatkan ekstrak etanol ganggang hijau dosis $250 \mathrm{mg} / \mathrm{KgBB}$ dan induksi isoproterenol dosis $85 \mathrm{mg} / \mathrm{KgBB}$

Kelompok IV: Kelompok EEGH 500 mendapatkan ekstrak etanol ganggang hijau dosis $500 \mathrm{mg} / \mathrm{KgBB}$ dan induksi isoproterenol dosis $85 \mathrm{mg} / \mathrm{KgBB}$

Kelompok V: Kelompok EEGH 750 mendapatkan ekstrak etanol ganggang hijau dosis $750 \mathrm{mg} / \mathrm{KgBB}$ dan induksi isoproterenol dosis $85 \mathrm{mg} / \mathrm{KgBB}$

Kelompok VI: Kelompok kontrol positif mendapatkan melatonin dosis $10 \mathrm{mg} / \mathrm{KgBB}$ dan induksi isoproterenol dosis $85 \mathrm{mg} / \mathrm{KgBB}$.

Pada hari ke-31 tikus diambil organ jantungnya untuk pengamatan parameter histopatologi. Jantung pada bagian ventrikel kiri yang telah disimpan dalam formalin $10 \%$. dibuat paraffin setebal 5 mikro meter dengan microtome. Pembuatan blok parafin jantung dilakukan di Laboratorium Patologi, Fakultas Kedokteran Hewan UGM. Jantung dimasukkan dalam kain kasa, didehidrasi dan direndam dalam larutan etanol bertingkat yaitu 70, 80, 90, 100 dan 100\% masing-masing selama 60 menit pada suhu kamar. Proses selanjutnya dilakukan penjernihan (clearing) menggunakan xylol selama 15 menit pada suhu kamar sebanyak tiga kali. Setelah proses clearing dilakukan proses infiltrasi dengan parafin cair sebanyak 3 kali pemindahan, masing-masing 60 menit dalam inkubator suhu $60^{\circ} \mathrm{C}$. Jaringan 
kemudian dibenamkan dalam parafin cair dan didinginkan dalam suhu kamar sehingga menjadi blok parafin. Blok parafin dipotong horisontal menggunakan mikrotom dengan ketebalan (t) $3 \mu \mathrm{m}$ (Widyaningsih et al, 2016).

Prosedur pengecatan COX-2 dilakukan di Laboratorium Patologi Anatomi, Rumah Sakit Sardjito, Yogyakarta, menggunakan protokol Starr Trek Universal Detection System (Biocare Medical, Concord, California). Potongan horisontal $(3 \mu \mathrm{m})$ blok parafin organ jantung dipilih dan diletakkan pada gelas obyek poly-L-lysin. Slide tersebut kemudian diinkubasi semalaman pada suhu $45^{\circ} \mathrm{C}$. Kemudian dilakukan deparafinisasi dalam xylene dan dilanjutkan dengan rehidrasi menggunakan alkohol bertingkat (99, 96, 70\%). Slide diinkubasi dalam $\mathrm{H}_{2} \mathrm{O}_{2} 3 \%$ selama 15 menit dan dicuci dengan air kran. Retrieving dilakukan dalam buffer citrat pH 6 menggunakan decloacking chamber pada suhu $95^{\circ} \mathrm{C}$ selama 40 menit, kemudian ditempatkan pada suhu kamar selama 30 menit. Protein blocking dilakukan menggunakan background sniper dengan menginkubasi slide selama 15 menit. Antibodi primer (Rabbit Polyclonal Anti-COX-2 Antibody) dengan pengenceran 1:100 diteteskan. Sebuah slide tanpa ditetesi antibodi primer juga dibuat untuk kontrol negatif. Slide tersebut kemudian ditempatkan pada suhu kamar selama 1 jam, selanjutnya dicuci dengan PBS selama 5 menit. Trekkie Universal Link, yang mengandung biotinylated secondary antibody, diteteskan kemudian diinkubasi pada suhu ruangan selama 20 menit. Slide kemudian dicuci dengan PBS. Trek Avidin-HRP diteteskan dan dicuci dengan PBS. Selanjutnya diteteskan larutan Benzoid DAB Chromogen dan dibiarkan 3 menit pada suhu ruangan. Diberi Haematoxylin sebagai counter-stain. Slide kemudian didehidrasi menggunakan alkohol bertingkat dan dijernihkan dengan xylene. Akhirnya dilakukan mounting dan cover-slipped, dilanjutkan pengamatan di bawah mikroskop. Sel yang mengalami inflamasi akan mengalami perubahan morfologi sel, yang dicirikan dengan adanya ekspresi protein COX-2 yang tercat berwarna coklat pada sitoplasma, dan nukleus di sel jantung. Perhitungan ekspresi COX-2 dilakukan dengan menggunakan aplikasi Image J. Persen ekspresi COX-2 dihitung dengan persamaan 1 (Kosik-Bogacka et al, 2016).

$\%$ ekspresi protein COX $-2=\frac{\text { inti sel yang mengekspresikan COX }-2}{\text { total sel terhitung }} \times 100 \%$ 
Analisis Data

Data ekspresi COX-2 yang diperoleh dianalisis distribusinya dengan uji Kolmogorof Smirnof dan diuji homogenitas datanya dengan uji Levene. Setelah didapatkan datanya terdistribusi normal dan homogen dilanjutkan dengan uji Anova dan uji beda antar kelompok dengan uji LSD.

\section{HASIL DAN PEMBAHASAN}

Pemberian ISO dosis $85 \mathrm{mg} / \mathrm{KgBB}$ menyebabkan infark myokardial akut yang ditunjukkan dengan adanya inflamasi (Grimm et al., 1998; Rathore et al., 1998). Untuk mengidentifikasi adanya inflamasi pada myokardium diketahui dari ekspresi enzim COX-2. Enzim sikloogsigenase (COX) merupakan enzim utama yang berperan di dalam terjadinya inflamasi. Enzim COX-2 hanya meningkat pada daerah yang mengalami inflamasi. Ekspresi COX-2 yang berlebihan ditemukan berhubungan dengan peningkatan produksi PGE2, Interleukin-1 (IL-1) yang berhubungan dengan IMA telah menunjukkan peningkatan ekspresi COX-2 (Rishikesh dan Sadhana, 2003).

Hasil penelitian menunjukkan bahwa pemberian ISO dosis $85 \mathrm{mg} / \mathrm{KgBB}$ menyebabkan terjadinya inflamasi pada jantung ditandai dengan peningkatan ekspresi COX-2 secara signifikan. Pada kelompok yang diberi ISO terlihat jumlah sel yang mengeskpresikan COX-2 lebih banyak daripada kelompok tanpa ISO. Gambar hasil imunohistokimia kelompok yang diberi ISO dengan yang tanpa ISO tersaji pada Gambar 1.

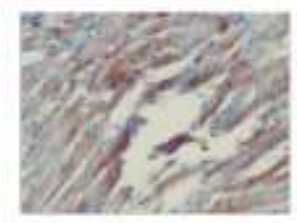

K. Negatif

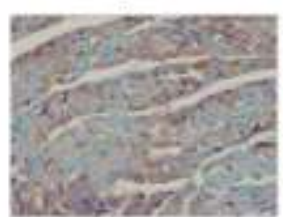

EEtit 500

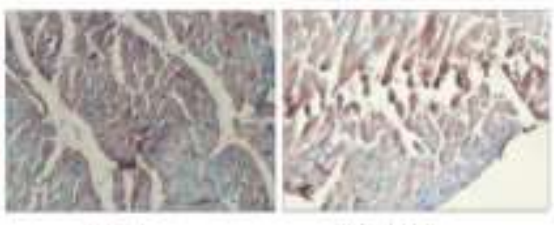

EEUL 250

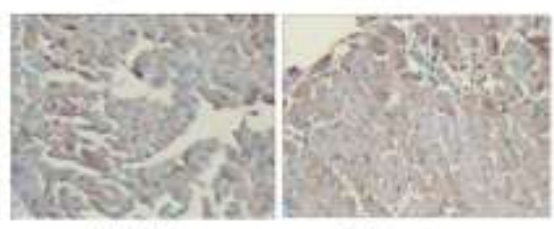

EEtr. 750

Melatesin

Gambar 1. Gambaran mikroskopis ekspresi protein COX-2 jantung tikus yang diberi isoproterenol pada berbagai kelompok. Pengecatan dilakukan dengan imunohistokimia dengan perbesaran $400 \mathrm{x}$ 
Induksi ISO menyebabkan gangguan keseimbangan antara pembentukan radikal bebas dan sistem pertahanan antioksidatif serta nekrosis otot jantung (Rathore et al., 1998). Adanya nekrosis pada otot jantung ditandai dengan adanya infiltrasi sel radang. Adanya radang ditunjukkan dengan peningkatan ekspresi protein COX-2. Hasil ini diperkuat dengan perhitungan persen ekspresi COX-2 sekitar 2 kali lipat dibanding dengan kelompok tanpa perlakuan ISO. Data perhitungan ekspresi COX-2 tersaji pada Tabel I dan Gambar 2.

Tabel I. Efek ekstrak etanol ganggang hijau (Ulva lactuca L) terhadap ekspresi COX-2 jantung tikus yang diinduksi isoproterenol

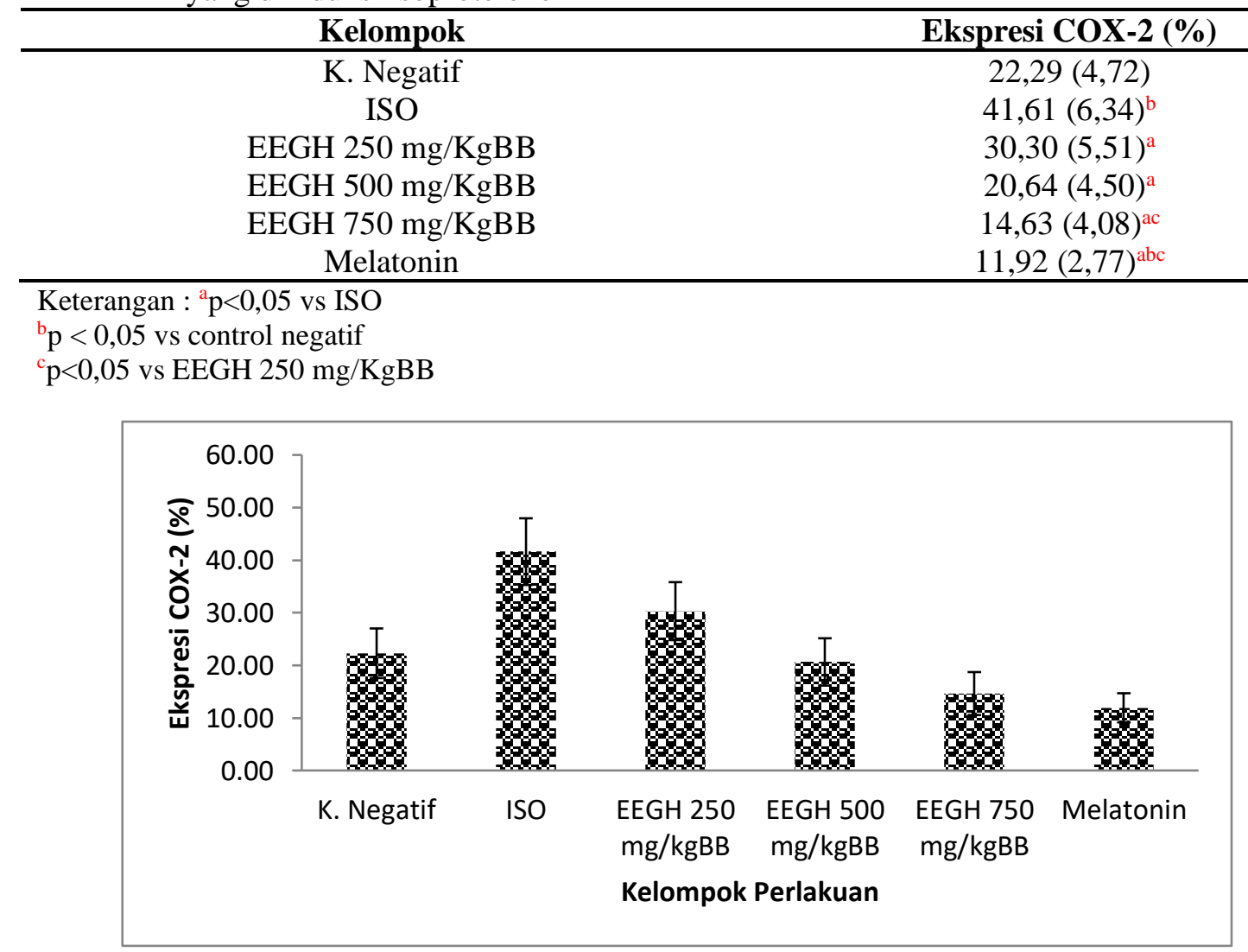

Gambar 2. Persen ekspresi COX-2 pada berbagai kelompok yang diberi ekstrak etanol ganggang hijau berbagai dosis.

Pada kelompok yang diberi EEGH berbagai dosis dan melatonin menunjukkan adanya penurunan ekspresi COX-2 dibanding kelompok ISO secara signifikan. Hasil ini menunjukkan bahwa pemberian EEGH berbagai dosis dan melatonin dapat menurunkan 
inflamasi pada otot jantung yang ditandai dengan penurunan ekspresi COX-2. Dalam proses inflamasi, COX-2 berperan pada proses inisiasi dan resolusi. Pada kondisi COX-2 yang terekspresi berlebih akan memicu pembentukan PGD2, sementara hanya sedikit PGE2 terbentuk, dimana PGD2 merupakan mediator inflamasi dan PGE2 berperan dalam homeostasis. Selain itu, pada kondisi ekspresi yang tidak berlebih, COX-2 melalui jalur asam arakidonat membentuk PGI2 yang dapat menghambat terjadinya agregasi platelet. Penurunan ekspresi COX-2 dapat mengurangi inflamasi yang terjadi serta berperan sebagai kardioprotektif dengan menghambat agregasi platelet (Sudewa dan Budiarta, 2017).

Ganggang hijau telah diteliti mengandung melatonin ((Paredes et al, 2009; Balzer dan Hardeland, 1996; Kolár dan Machácková, 2005; Tal et al., 2011) demikian juga EEGH (Widyaningsih et al., 2016). Melatonin telah diketahui mempunyai potensi sebagai antioksidan. Mekanisme antioksidan dapat menurunkan resiko terjadinya infark miokard pada otot jantung sehingga berpotensi melindungi otot jantung dari kerusakan akibat stress oksidatif. Aktivitas antioksidan dan kardioprotektif melatonin telah dilaporkan pada penelitian sebelumnya (Tal et al., 2011; Reiter and Tan, 2003). Melatonin dan metabolitnya ( $\mathrm{N}_{1}$-acetyl $\mathrm{N}_{2}$-formil-5 metoxykynuramine (AFMK) (Abd-Ellatef et al., 2017) and N-acetyl-5metoxykynuramin (AMK) mencegah oksidatif stress serta meningkatkan antioksidan endogen seperti SOD, Cat dan GPx (Francis et al., 2002).

EEGH tidak hanya mengandung melatonin. Penelitian terdahulu menunjukkan bahwa U. lactuca $L$ mengandung klorofil, karetonoid, vitamin C, polifenol dan polisakarida sulfat yang berfungsi sebagai antioksidan. Aktivitas antioksidan dan antiapoptosis polisakarida sulfat yang berasal dari U.lactuca dapat mencegah kanker payudara dengan mekanisme antioksidan, antiapoptosis dan menekan inflamasi (He et al., 2016). Aktivitas antioksidan dan aktivitas antiapoptosis dari EEGH diduga berperan pada aktivitas penekanan inflamasi sehingga melindungi sel jantung dari kerusakan. EEGH dalam penelitian sebelumnya mempunyai aktivitas kardioprotektif (Widyaningsih et al., 2016) dengan mekanisme antioksidan dan antiapoptosis (Widyaningsih et al., 2017). Hasil penelitian ini menunjukkan bahwa efek menurunkan ekspresi COX-2 pada penelitian ini bukan hanya karena kandungan melatonin tetapi kemungkinan karena kombinasi melatonin dengan senyawa lain dalam EEGH. Polisakarida sulfat dari U.lactuca mempunyai aktivitas antioksidan ( de Araújo et al, 
2016) dan antiinflamasi melewati jalur bradikinin dan menurunkan ekspresi protein COX-2 (Ahmed et al., 2017). Ekstrak etanol 70\% dari U. lactuca mempunyai aktivitas antiartitis dengan mekanisme antiinflamasi dan antioksidan (Pietta, 2000). Penelitian terdahulu menunjukkan EEGH mengandung flavonoid yang bersifat antioksidan dan saponin (Liu dan $\mathrm{Ng}$, 2000) dengan metabolit yang unik yaitu 2,3-dihydro-2,5-dihydroxy-6-methyl-4H-pyran4-one (DDMP), yang bersifat antioksidan sehingga mencegah kerusakan biomolekuler(Abd et al., 2017). Mekanisme antioksidan dan antiapoptosis dari EEGH inilah yang dapat menekan inflamasi dan mengurangi IMA. Penurunan ekspresi COX-2 setelah pemberian EEGH yang menjadi parameter berkurangnya inflamasi. Dengan berkurangnya inflamasi tersebut, maka berkurangnya resiko IMA pada jantung.

\section{KESIMPULAN}

Pemberian ekstrak etanol ganggang hijau mampu menurunkan ekspresi COX-2 pada tikus yang diinduksi isoproterenol. Dosis ekstrak etanol ganggang hijau yang dapat menurunkan ekspresi COX-2 adalah dosis 250, 500 dan $750 \mathrm{mg} / \mathrm{kgBB}$.

\section{UCAPAN TERIMA KASIH}

Terima kasih kepada Lembaga Penelitian UAD yang telah membiayai penelitian ini dengan hibah Fundamental LPP UAD dengan No Perjanjian Pelaksanaan Penelitian PF025/SP3/LPP-UAD/IV/2017.

\section{DAFTAR PUSTAKA}

Abirami RG, Kowsalya S. 2011, Nutrient and Nutraceutical Potentials of Seaweed Biomass Ulva lactuca and Kappaphycus alvarezii. J Agric Sci Technol. 5(1):107-15.

Abd-Ellatef G-EF, Ahmed OM, Abdel-Reheim ES, Abdel-Hamid A-HZ.2017, Ulva lactuca polysaccharides prevent Wistar rat breast carcinogenesis through the augmentation of apoptosis, enhancement of antioxidant defense system, and suppression of inflammation. Breast Cancer Dove Med Press. 9:67-83. 
Ahmed OM, Soliman HA, Mahmoud B, Gheryany RR., 2017, Ulva lactuca hydroethanolic extract suppresses experimental arthritis via its anti-inflammatory and antioxidant activities. Beni-Suef Univ J Basic Appl Sci. 6(4):394-408.

Anonim. WHO, 2016, | Cardiovascular diseases (CVDs) [Internet]. WHO. [dikutip 26 Januari 2017]. Tersedia pada: http://www.who.int/cardiovascular_diseases/en/

Balzer I, Hardeland R., 1996, Melatonin in Algae and Higher Plants - Possible New Roles as a Phytohormone and Antioxidant. Bot Acta. 109(3):180-3.

Carnieto A, Dourado PMM, da Luz PL, Chagas ACP. 2009, Selective Cyclooxygenase-2 Inhibition Protects Against Myocardial Damage in Experimental Acute Ischemia. Clin Sao Paulo Braz. ;64(3):245-52.

de Araújo IWF, Rodrigues JAG, Quinderé ALG, Silva J de FT, Maciel G de F, Ribeiro NA, 2016, Analgesic and anti-inflammatory actions on bradykinin route of a polysulfated fraction from alga Ulva lactuca. Int J Biol Macromol. 92:820-30.

Einav R, Israel A. 2007, Seaweeds on the Abrasion Platforms of the Intertidal Zone of Eastern Mediterranean Shores. Dalam: Seckbach J, editor. Algae and Cyanobacteria in Extreme Environments [Internet]. Dordrecht: Springer Netherlands; [dikutip 13 April 2016]. hlm. 193-207. Tersedia pada: http://link.springer.com/10.1007/978-1-4020-6112-7_10

El Baky HHA, El Baz FK, El Baroty GS. 2009, Potential Biological Properties of Sulphated Polysaccharides Extracted from the Macroalgae Ulva lactuca L. Acad J Cancer Res. 2(1):01-11.

El Gamal AA. 2010, Biological importance of marine algae. Saudi Pharm J SPJ.;18(1):1-25.

Francis G, Kerem Z, Makkar HPS, Becker K., 2002. The biological action of saponins in animal systems: a review. Br J Nutr. 88(6):587-605.

Gimbrone MA, Topper JN, Nagel T, Anderson KR, Garcia-Cardeña G., 2000, Endothelial dysfunction, hemodynamic forces, and atherogenesis. Ann N Y Acad Sci.;902:230-239; discussion 239-240.

Grimm D, Elsner D, Schunkert H, Pfeifer M, Griese D, Bruckschlegel G, 1998, Development of heart failure following isoproterenol administration in the rat: role of the reninangiotensin system. Cardiovasc Res. 37(1):91-100.

Hardeland R, Poeggeler B. 2003, Non-vertebrate melatonin. J Pineal Res.;34(4):233-41. 
He J, Xu Y, Chen H, Sun P.2016, Extraction, Structural Characterization, and Potential Antioxidant Activity of the Polysaccharides from Four Seaweeds. Int J Mol Sci. 28 17(12).

Kolár J, Machácková I. 2005, Melatonin in higher plants: occurrence and possible functions. $J$ Pineal Res. 39(4):333-41.

Kosik-Bogacka DI, Baranowska-Bosiacka I, Kolasa-Wołosiuk A, Lanocha-Arendarczyk N, Gutowska I, Korbecki J, 2016,. The inflammatory effect of infection with Hymenolepis diminuta via the increased expression and activity of COX-1 and COX-2 in the rat jejunum and colon. Exp Parasitol. 169:69-76.

Liu F, Ng TB. 2000, Effect of pineal indoles on activities of the antioxidant defense enzymes superoxide dismutase, catalase, and glutathione reductase, and levels of reduced and oxidized glutathione in rat tissues. Biochim Biol Cell. 78(4):447-53.

Martinez MJA, Olmo LMBD, Benito PB. 2005, Antiviral Activities of Polysaccharides from Natural Sources. Dalam: Atta-ur-Rahman, editor. Studies in Natural Products Chemistry [Internet]. Elsevier; [dikutip 26 Januari 2017]. hlm. 393-418. (Bioactive Natural Products (Part K); $\quad$ vol. 30 . Tersedia pada: //www.sciencedirect.com/science/article/pii/S1572599505800389

Pape C, Lüning K. 2006, Quantification of melatonin in phototrophic organisms. J Pineal Res. 41(2):157-65.

Paredes SD, Korkmaz A, Manchester LC, Tan D-X, Reiter RJ.2009, Phytomelatonin: a review. J Exp Bot. 60(1):57-69.

Pietta PG. Flavonoids as antioxidants. 2000, J Nat Prod. 63(7):1035-42.

Rathore N, John S, Kale M, Bhatnagar D.1998, Lipid peroxidation and antioxidant enzymes in isoproterenol induced oxidative stress in rat tissues. Pharmacol Res Off J Ital Pharmacol Soc.;38(4):297-303.

Reiter RJ, Tan D-X. 2003, Melatonin: a novel protective agent against oxidative injury of the ischemic/reperfused heart. Cardiovasc Res. 58(1):10-9.

Rishikesh MK, Sadhana SS. 2003, Prostaglandins and cyclooxygenase: Their probable role in cancer. Indian J Pharmacol. 35(1):3. 
Robic A, Sassi J-F, Lahaye M. 2008, Impact of stabilization treatments of the green seaweed Ulva rotundata (Chlorophyta) on the extraction yield, the physico-chemical and rheological properties of ulvan. Carbohydr Polym. 74(3):344-52.

Rodrigo R, Libuy M, Feliú F, Hasson D., 2013, Oxidative Stress-Related Biomarkers in Essential Hypertension and Ischemia-Reperfusion Myocardial Damage. Dis Markers.;35(6):773-90.

Sathivel A, Raghavendran HRB, Srinivasan P, Devaki T. 2008, Anti-peroxidative and antihyperlipidemic nature of Ulva lactuca crude polysaccharide on D-galactosamine induced hepatitis in rats. Food Chem Toxicol Int J Publ Br Ind Biol Res Assoc.;46(10):3262-7.

Tal O, Haim A, Harel O, Gerchman Y. 2011, Melatonin as an antioxidant and its semi-lunar rhythm in green macroalga Ulva sp. J Exp Bot.62(6):1903-10.

Widyaningsih W, Pramono S, Widyarini S, Sugiyanto S. 2016, Skrining fitokimia ekstrak etanol Ulva lactuca 1. dengan metode kromatografi lapis tipis. Media Farm.;13(2):199_ 211.

Widyaningsih W, Pramono S, Widyarini S, Sugiyanto. 2016, Cardioprotective Effect of Melatonin-Standardized Ethanol Extract of Ulva lactuca L against Acute Myocardial Infarction in Rats Induced by Isoproterenol. Trop J Pharm Res. 15(8):1723-9.

Widyaningsih W, Pramono S, Zulaela, Sugiyanto, Widyarini S. 2017, Protection by Ethanolic Extract from Ulva lactuca L Against Acute Myocardial Infarction: Antioxidant and Antiapoptotic Activities. Malays J Med Sci. 24(6):39-49.

Zhang G-X, Kimura S, Nishiyama A, Shokoji T, Rahman M, Yao L, 2005,. Cardiac oxidative stress in acute and chronic isoproterenol-infused rats. Cardiovasc Res. 1;65(1):230-8. 